\title{
THE MARTIN FLYNN FARM: FROM PUBLIC LAND IN 1845 TO LIVING HISTORY FARMS IN 1970*
}

\author{
by William G. Murray \\ Ames, lowa
}

Dr. Murray is Research Director of the Living History Farms and a Professor of Economics at Iowa State University, Ames, Iowa.

In 1867 Martin Flynn bought 600 acres of farm land eight miles northwest of Des Moines. He built a stately brick home, a large horse barn, and other buildings; he developed an outstanding herd of Shorthorn cattle, and increased the size of his farm, called Walnut Hill, to 1280 acres by 1870 .

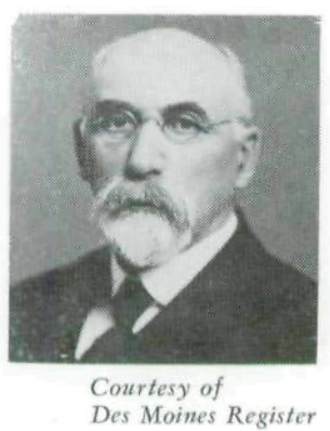

Martin Flynn

Recent events have generated a lively interest and a host of questions regarding Martin Flynn's farm and family, and what happened to the farm after the Flynns sold it. After Martin Flynn died in 1906 the family held onto the farm until 1915 when they sold it to the State of Iowa which transformed the land and buildings into an honor prison farm. In 1957 the Interstate highway was built through the farm just west of the farmstead, and in 1965 the State sold the whole farm to Rollo Bergeson and Associates. In 1969 Rollo Bergeson sold 171 acres of the land west of the Interstate to Living History Farms, and in December of 1970 the Bergeson family gave the Living History Farms a 25.5 acre tract east of the Interstate. This tract includes the Flynn Mansion.

A chronological record of the land which included the original Flynn farmstead provides a fascinating background

${ }^{\circ}$ Grateful acknowledgment is made to the following for their assistance in providing information and reviewing the manuscript: Mrs. John A. Flynn whose late husband was a grandson of Martin Flynn, Mrs. Lida L. Greene, LeRoy G. Pratt, and William J. Wagner who sketched the Flynn Mansion for the cover of this issue of the ANNALS. 
for the use that has been made of this land over the years. The skeleton record reads as follows:

\section{Chronological Record of Martin Flynn Farmstead Area}

Prior to 1845-Occupied and owned by Sac and Fox Indians. 1845 - Sac and Fox Indians give up possession following agreement in Treaty of 1842. Land becomes part of U.S. Public Domain.

1847-Survey of land by Federal surveyors.

1848-Land offered for sale at $\$ 1.25$ an acre by Federal Government at Land Office in Iowa City.

1849-John Lewis buys 160 acres, containing land which later was Flynn Farmstead. Price $\$ 1.25$ an acre approximately.

1860-Jonathon Lewis sells 265 acres to E. R. Clapp. Price $\$ 10.00$ an acre.

1867-E. R. Clapp sells 600 acres to Martin Flynn. Price $\$ 26.67$ an acre.

1915-Flynn Farms Co. (Flynn Estate) sells 800 acres to the State of Iowa for the price of $\$ 200.00$ per acre.

1965-State of Iowa sells 687 acres to Rollo Bergeson and Associates on highest bid. Price $\$ 1,100.00$ an acre.

1969-Rollo Bergeson sells 171 acre tract west of Interstate to Living History Farms. Price $\$ 1,200.00$ an acre.

1970-Rollo Bergeson leases to Living History Farms, with option to buy, a tract of 165 acres. Later, Bergeson family gives the Farms 25.5 acre tract, including the Flynn Mansion.

The story starts with the Sac and Fox Indians who were recognized by the Federal Government as the original owners of a large portion of central and eastern Iowa, including the land which eventually becomes the Martin Flynn Farm. In 1845 the Sac and Fox Indians gave up possession of the area which contained the Flynn Farm.

Next came the official land survey; the contract for which was made in 1847. The survey of Township 79-25, which contained the Flynn land, was started September 28, 1847 and completed October 2, 1847. In his report on this township, which included the Flynn land, the surveyor wrote:

This Township is mostly high rolling prairie, generally first rate soil. 
A portion of S.W. part of the Township along the breaks of Walnut Creek is broken and covered with oak, hickory and hazle bushes, red root etc., with scattering and inferior oak and hickory timber.

Beaver Creek is a very large and beautiful creek affording many favorable sites for mills. The prairie contiguous to it is beautiful, and where there is timber sufficient will invite the attention of the pioneer seeking a location for a farm.

\section{Saml. W. Durham}

Dept. Surveyor

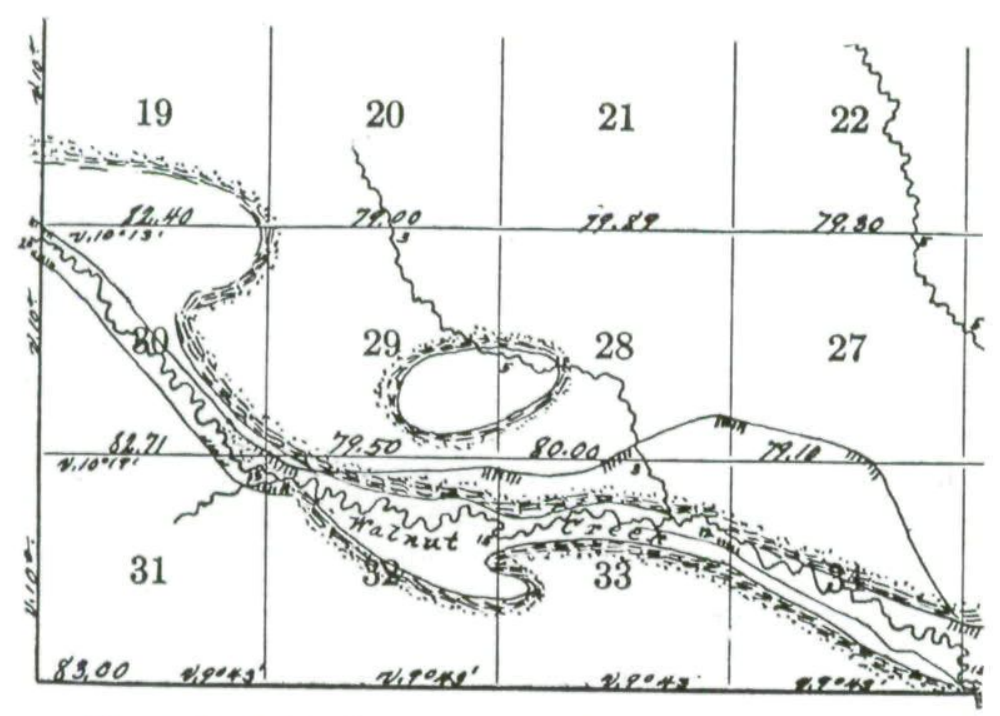

Figure 1. Original survey plat of southwest portion of Township 79-25 (Walnut Township). This plat was made in 1847 as part of the survey completed in that year. Eggshaped area in section 28 and 29 , and area inside wide boundary line along Walnut Creek indicates timber.

A special feature of the original survey was the map prepared by the surveyor. The portion of the township map for Twp. 79-25 containing the Flynn Farm is shown above in Figure 1. Of particular signficance to our record is the grove of timber which the surveyor located in the southwest part of Section 28 and the eastern part of Section 29. This later became the center of the Flynn Farm. 
In 1848 the land in Twp. 79-25 was officially offered for sale at the Land Office at Iowa City. The price was the same for each and every acre in the township that was offered for sale $-\$ 1.25$ an acre or a military land warrant which could usually be bought at a price somewhat less than $\$ 1.25$ an acre. Since all acres were available at the same price, where the first settler bought was a good indication of what was considered the best land at that time.

The first purchase in the southwest part of Twp. 79-25 was 160 acres in Sections 29 and 29, containing a major portion of the grove of timber shown in these sections in Figure 1. The part in Section 28 became the location of the Flynn Farmstead. John Lewis, who made his first purchase, paid for the land with a military land warrant which probably cost him less than $\$ 1.25$ an acre or less than $\$ 200.00$.

The reason John Lewis bought this land in 1849-three years before anyone else bought in the area-was probably because the land had this grove of timber as well as a flowing stream and good prairie nearby. This combination of features-timber, water, and prairie-was the combination which appealed to the settler who wanted timber for fuel, building material, fencing, protection from the elements, easy access to water for his family and his livestock, and prairie which could be easily broken for cultivation without having to clear the land of trees and brush.

North of the land bought by John Lewis in 1849, the Living History Farms has located its Pioneer Farm on the edge of the timber, near a small stream with prairie nearby. In the summer of $1970 \mathrm{Mr}$. Darwin Thede, the Pioneer Farmer for Living History Farms, started to build his crude cabin out of burr oak logs cut from the timber in the area. Thus, in 1970 the making of a pioneer farm was carried out similar to the way it was done in this same area in the late 1840's.

In 1860 a new development began to take shape in the southwest part of Twp. 79-25. A Des Moines businessman, E. R. Clapp, started buying land in this area. What he did is shown in Table 1 which shows the historical record for the tracts he bought. 


\section{Table 1 \\ Historical Record of the 600 Acres Sold by E. R. Clapp to Martin Flynn in $1867^{1}$}

\begin{tabular}{|c|c|c|c|c|c|c|}
\hline \multirow{2}{*}{$\begin{array}{l}\text { Section and } \\
\text { Tract }^{2}\end{array}$} & \multirow[b]{2}{*}{ Acres } & \multicolumn{3}{|c|}{$\begin{array}{l}\text { Bought from the } \\
\text { Government }\end{array}$} & \multicolumn{2}{|c|}{$\begin{array}{l}\text { Bought by } \\
\text { E. R. Clapp } \\
\text { Price }\end{array}$} \\
\hline & & Year & Buyer & $\begin{array}{c}\text { Price } \\
\text { Per Acre }\end{array}$ & & \\
\hline \multicolumn{7}{|l|}{ Section 28} \\
\hline 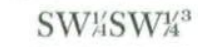 & 40 & 1849 & J. Lewis & $\mathrm{Wt}^{5}$ & 1860 & $\$ 10.00$ \\
\hline $\mathrm{NW}^{1 / 4} \mathrm{SW}^{1 / 4}$ & 40 & 1849 & J. Lewis & Wt. & 1860 & 10.00 \\
\hline $\mathrm{SE} 1 / 4 \mathrm{SW}^{1 / 4}$ & 40 & 1849 & J. Lewis & Wt. & 1860 & 10.00 \\
\hline $\mathrm{NE}_{4}^{1} \mathrm{SW}^{1}{ }_{4}^{\prime}$ & 40 & 1855 & E. Lucas & Wt. & 1862 & 12.50 \\
\hline \multicolumn{7}{|l|}{ Section 29} \\
\hline $\mathrm{NE}^{1 / 4}$ & 160 & 1853 & J. Gill & $\$ 1.25$ & 1865 & 5.00 \\
\hline $\mathrm{NE}^{1 / 4} \mathrm{SE}^{1 / 4}$ & 40 & 1849 & J. Lewis & Wt. & 1860 & 10.00 \\
\hline $\mathrm{NW}^{1 / 4} \mathrm{SF} / 1 / 4$ & 40 & 1854 & A. Stevens & Wt. & 1865 & 13.65 \\
\hline $\mathrm{NE}^{1 / 4} \mathrm{SW}^{1 / 4}$ & 40 & 1854 & J. Hamilton & 1.25 & 1865 & 13.65 \\
\hline \multicolumn{7}{|l|}{ Section 33} \\
\hline $\mathrm{N}_{1} / 2 \mathrm{NE}_{1}^{1} / 4$ & 80 & 1851 & E. W & Wt. & 18 & 3.75 \\
\hline $\mathrm{NE}^{1} / 4 \mathrm{NW}^{\prime} / 4$ & 40 & 1852 & J. Lewis & Wt. & 1860 & 10.00 \\
\hline $\mathrm{NW}^{1 / 1} \mathrm{NW}^{1 / 4}$ & 40 & 1854 & A. Stevens & Wt. & 1860 & 10.00 \\
\hline & & & & & & 85 \\
\hline
\end{tabular}

${ }^{1}$ Data for this table obtained from records in Recorder's Office in the Polk County Courthouse.

${ }^{2}$ All sections and tracts are in Township 79 North, Range 25 West of the Fifth Principal Meridian. This portion of the survey township is called Walnut Township.

${ }^{3}$ This is the tract where the Flynn farmstead is located.

${ }^{4}$ In the SW/4 of the NE $/ 4$ is located the "Pioneer" 1840 Farm of the Living History Farms.

${ }^{5} \mathrm{Wt}$. stands for military land warrant. These warrants given for military service were bought and sold in the market at $\$ 1.25$ an acre or less and usually less.

The first purchase of E. R. Clapp was from the Lewis family in 1860. One of the interesting transactions was a 40 acre tract (NE/ SW/4 of Sec. 28) bought originally by $\mathrm{E}$. W. Lucas in 1855 . Three years later Mr. Lucas sold this 40 acre tract to Samuel J. Kirkwood and Ezekiel Clark who in turn sold it to E. R. Clapp in 1862. Samuel J. Kirkwood served as Governor of Iowa during the Civil War years, 1860-1864 and again 1876-1877, when he resigned to run for and was elected to the U. S. Senate.

Another interesting case was the $\mathrm{NE}^{1 /}$ of the SW Section 29 bought from the government by J. Hamilton in 
1854. Hamilton sold this tract to E. Frazier in 1855, who in turn sold to W. Mordock in 1856. Mordock sóld to H. Gibson in the same year. Gibson sold to S. Wilson in 1858, who sold to F. Wilson in the same year. F. Wilson sold to J. Crow in 1859 who sold to E. R. Clapp in 1865 . In all there were eight sales in an eleven year period.

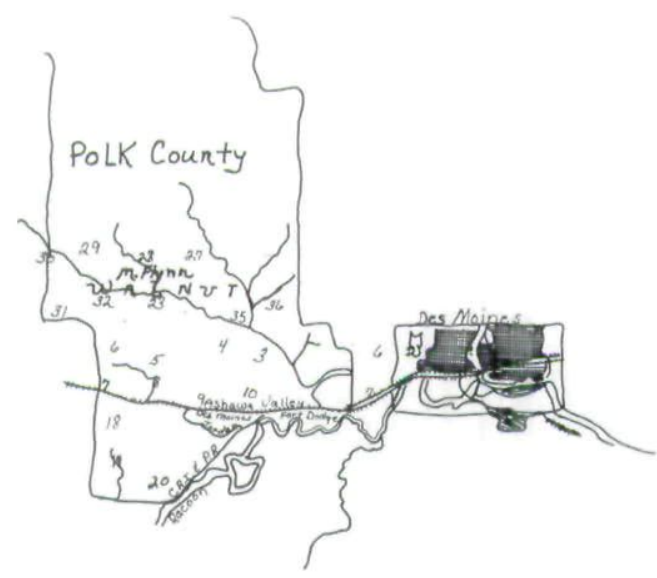

Figure 2. Map showing location of Martin Flynn farm in Section 28, Twp. 79-25, (Walnut Twp.) in Polk County, and its dist a n ce from Des Moines in the same county. Based on map on page 181 of And rea s' "Atlas of lowa", 1875.

E. R. Clapp paid an average of $\$ 8.55$ an acre or $\$ 5,150$ total for the 600 acres he bought between 1860 and 1865. His sale to Martin Flynn, according to the records, totalled $\$ 16,000$ or $\$ 26.67$ an acre, giving Clapp a net gain of $\$ 10,850$ on this transaction.

Where did Martin Flynn obtain the funds to buy the 600 acres, to buy an additional 680 acres by 1870, and to build the large home and barn? The money came from Martin Flynn's work as a contractor of railroad grades. He was born in Ireland in 1840. He came to this country in 1851 and worked his way up in railroad right-of-way construction until in 1861, at the age of 21 , he secured an important contract with the Union Pacific Railroad. Later he had contracts with the Chicago and Northwestern, Chicago and Rock Island, and other railroads. Even after he purchased the farm in 1867 and made his home here, he continued his railroad contracting, as for example his contract in 1878 to build the Raton Tunnel in New Mexico for the Santa Fe Railroad. 
In the Federal Census report for 1870 Martin Flynn gave his occupation as "Railroad Contractor and Farmer."

Martin Flynn married Ellen Keane in Nebraska in 1864. Their first child, Thomas, was born in Nebraska. In 1867 the family moved to Iowa, residing first in Jasper County, east of Des Moines, then to the 600 acre farm purchased from E. R. Clapp.

The Flynn family made their home at the Walnut Hill Farm. In 1889, Mr. and Mrs. Martin Flynn acquired a house in Des Moines but continued their main residence on the farm. In Table 2 the members of the family are shown as listed in the census reports of 1870 \& 1885 .

Table 2: Census Reports of Martin Flynn in Walnut Township, Polk County, lowa, 1870, and 1885*

Census Report

\begin{tabular}{|c|c|c|c|c|}
\hline & 1870 & & 1885 & \\
\hline Family & Age & & Age & Birthplace \\
\hline Flynn, Martin & 29 & - & 44 & Ireland \\
\hline Flynn, Ellen & 26 & - & 41 & Ireland \\
\hline Flynn, Thomas & 4 & 一 & 19 & Nebraska \\
\hline Flynn, Katherine & 3 & - & 17 & Jasper County \\
\hline Flynn, John M. & 1 & - & 15 & Polk County \\
\hline Flynn, Mary E. & & 一 & 13 & Polk County \\
\hline Flynn, Francis P. & & - & 9 & Polk County \\
\hline Flynn, William U. & & - & 7 & Polk County \\
\hline Flynn, Winifred A. & & - & 5 & Polk County \\
\hline Flynn, Nellie G. & & - & 3 & Polk County \\
\hline Flynn, Edward & & 一 & 2 & Polk County \\
\hline Flynn, Anna B. & & - & 1 & Polk County \\
\hline
\end{tabular}

${ }^{\circ}$ The 1870 Census was conducted by the Federal Government, the 1885 Census by the State of Iowa.

Martin Flynn actually took on a number of other interests besides his farm and railroad contracting. These interests included a large sheep ranch near Douglas, Wyoming, which his son John managed for many years, a brick yard, a bank and a business building in Des Moines.

The development of the Flynn farm is shown by the figures in Table 3, reported for the farm in the 1870 and 1880 Federal Census. These statistics, obtained from the original census schedules in the State Historical Library in Iowa 
City, Iowa, show a large increase in area of improved acres, production of crops, and numbers of livestock between 1870 and 1880.

Table 3: Martin Flynn Farm Data from Agricultural Schedules Item in Federal Census of 1870 and 1880

Acres, Total 1870

1880

Improved ............... 650

Woodland ................... 125

Unimproved ............... 505

Livestock

Horses ................. 18

Cattle .................... 40

Swine .................. 50

Crop production

Indian corn . . . . . . . . . 8,000 bu.

Wheat ................. 1,995 bu.

$20,000 \mathrm{bu}$. $600 \mathrm{bu}$.

Oats ................. $500 \mathrm{bu}$ $3,000 \mathrm{bu}$.

Rye $\ldots \ldots \ldots \ldots \ldots \ldots \ldots \ldots \ldots \ldots$ $1,000 \mathrm{bu}$.

Hay 100 tons 400 tons

Miscellaneous

Butter produced ............. 1,040 lbs.

Wages paid $\ldots \ldots \ldots \ldots \ldots \ldots \ldots 2,000$

500 lbs. $\$ 3,500$

Property taxes on the 600 acres bought by Martin Flynn were 15 cents an acre in 1868, the first full year of Flynn's ownership. The next year they jumped to 27 cents an acre and in 1870 averaged 26 cents an acre on his total acreage. The increase from 15 to 27 cents was probably due in part to the erection of new buildings.

A major contribution of Martin Flynn to Walnut Hill Farm was the house and barn which he built. They are both standing, and in relatively good condition after approximately one-hundred years of service. The large home was affectionately called "The Brick," according to Mrs. Orrin McIntyre of Des Moines who lived at the home before it was sold to the State in 1915. Three pictures of the Flynn Mansion are presented in Figures 3, 4, and 5. The first picture was taken in the 1870 's, the second around 1900, and the third in January 1970. The last picture also shows the large horse barn which is located east of the house. 


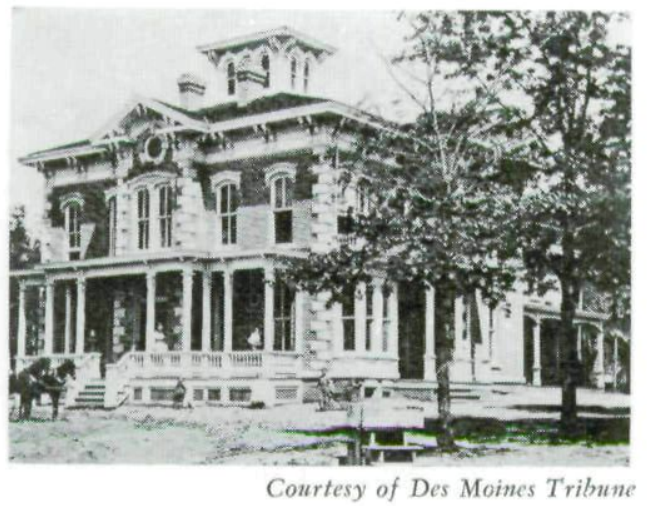

Figure 3. Flynn home as it appeared in the 1870's.

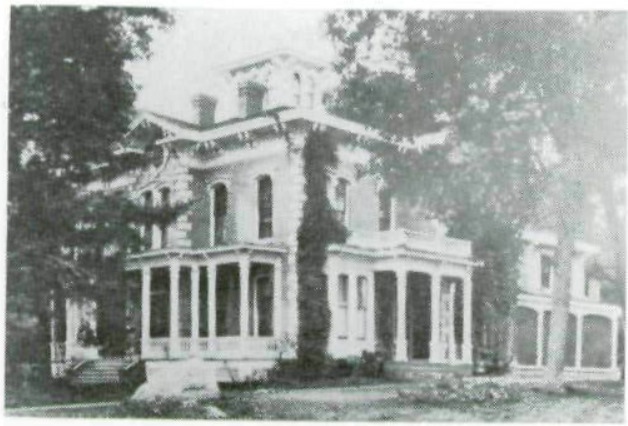

Figure 4. Picture of Flynn home around 1900. Note the heavier growth of trees compared to Figure 3 , the time is about 30 years after picture in Figure 3 . This picture appeared in MIDWESTERN MAGAZINE, May 1907.

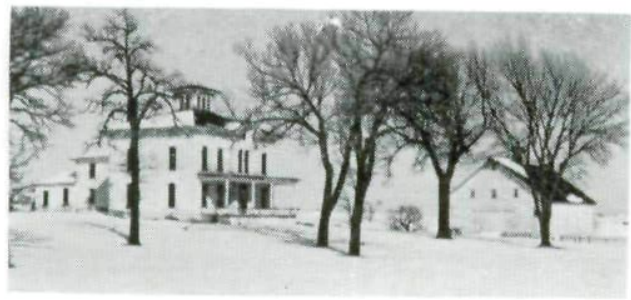

Courtesy of Rollo Bergeson

Figure 5. Picture of Flynn home and barn as they appeared on a winter day in January 1970. 
A comment on the social activities and hospitality shown to visitors at the Flynn Home appeared in the Midwestern Magazine of May 1907 (page 5) along with the picture of the home which appears in Figure 4. The comment follows:

Years ago when things were in a primeval state in Iowa, Mr. Flynn built and furnished the splendid home on his farm, then miles from Des Moines, which must go down in the history of the state as an ideal farm home, where the Flynns were the soul of true hospitality.

Guests from all parts of the world have been entertained here in most royal fashion. Mr. and Mrs. Flynn were ideal hosts and their latch-string was always out for their friends.

Soon after Martin Flynn bought the 600 acres in 1867, he started a herd of pedigreed Shorthorn cattle, getting a start by buying some outstanding Shorthorn animals in Tennessee. In a "Catalog of Short-Horn Bulls for Sale at Private Treaty from Walnut Hill Herd," issued in 1905, the following statement appears:

This lot represents the result of thirty-seven years experience in carefully breeding and raising Shorthorns. The herd was originally founded on the most approved strains of the day and the new blood since added has been of the very best that money could buy.

The copy of this catalog is owned by Mrs. John L. Flynn of Des Moines, the widow of John L. Flynn, grandson of Martin Flynn. Mrs. Flynn also owns a copy of a sale catalog entitled "27th Annnual Sale of Short Horns, Des Moines, Iowa, Wednesday and Thursday, October 11th and 12th, 1905, Martin Flynn \& Sons." In this catalog the following statement appears in the Announcement: "On account of our rapidly increasing herd, which now numbers over 350 head, we find it necessary to hold a two days' sale to reduce the herd sufficiently to comfortably carry it through the coming winter." The statement "thirty-seven years experience" indicates the beginning of the Shorthorn herd in 1868-69 shortly after Martin Flynn bought his original 600 acres in 1867. The " 27 th Annual Sale" in 1905 indicates that the first sale was held in 1879 if a sale was held each year beginning in 1879 .

Martin Flynn achieved an impressive record as a Shorthorn breeder. In the Homestead, a farm magazine published in Des Moines, a fine tribute to his contribution in livestock breeding appeared in the issue of July 19, 1906. In this article, which was written before his death but actually was printed 
on the day following his death on July 18, 1906, this statement appears:

Although the strenuous years of Mr. Flynn's life did not associate him with the livestock industry, yet it is his record as a breeder of Shorthorn cattle that stamps his name on corn-belt history. A man abounding in common sense and with almost unerring judgment, it was but natural that he should forge to the front when he took up in earnest the breeding of cattle. He became a close student of pedigree and has always been fearless in his method of mixing blood lines, without regard to the effect on pedigree. To improve the animal was his aim always, and the results attained have more than justified the means. Mr. Flynn stands today at the very top as a breeder of 'good cattle.'

Martin Flynn was also highly regarded as a livestock judge. This same article in the Homestead contains this statement:

As a juror in the beef cattle ring no man stands higher today in the opinion of successful men than Mr. Flynn. His work in this line at the principal expositions has always borne the stamp of honesty and his decisions have always been the result of a discriminating judgment.

Following the death of Mr. Flynn the Homestead of July 26th had this comment:

His death means the passing of no common man, and in him the profession of agriculture in all its branches loses a great leader, and the ranks of Shorthorn breeders has been bereaved of one of its most respected members, Mr. Flynn being a director of the Shorthorn breeders' association at the time of his death.

\section{State Honor Prison Farm}

Shortly before Martin Flynn's death in 1906, the Walnut Hill Farm was incorporated and named the Flynn Farm Company. In 1915 Walnut Hill Farm, comprising 800 acres including the farmstead, was sold to the State of Iowa for an honor prison farm for $\$ 200$ an acre. From that time to 1965 , a period of 50 years, the farm was used as a place for trusted prisoners, except for several years when it was leased out as a farm.

During the years the State had the farm, the Flynn Mansion was used as a headquarters for the prisoners. In the May 25, 1941 issue of the Des Moines Register appeared a story by C. C. Clifton which contained this statement:

The old Flynn mansion on the Clive farm now houses 48 trusty prisoners from the Fort Madison, Iowa, penitentiary who are operating the 781 acre farm, raising 191 acres of corn, 156 acres of oats, and 124 acres of alfalfa and clover in compliance with the AAA program. 
Mr. John Wabel, who was superintendent of the farm from 1941 until it was sold, made an outstanding record in operating the land and in supervising the prisoners during this period.

The Flynn Dairy of Des Moines was started in 1909 by Martin Flynn's sons after their father's death. The Flynn Dairy was reorganized in 1910 to include a group of physicians. For years, a special feature of the Flynn Dairy was the use of white Percheron horses on their milk delivery wagons.

\section{Interstate Highway}

In 1957, Interstate 80 and 35, which bypasses Des Moines on the north and west, was routed through the State Honor Prison Farm just west of the farmstead. This left a tract of 171 acres west of the Interstate separated from the farmstead buildings. Since the land at the time was owned by the State of Iowa, an unusual arrangement was madecompensation for the 73 acres of land taken by the Interstate was construction of a 12 foot by 14 foot underpass for the use of the Honor Prison Farm in getting tractors and farm machinery back and forth to the 171-acre tract west of the Interstate. This provides a unique situation as there are few private underpasses on the Interstate.

\section{State Farm to Bergeson to Living History Farms}

The State decided that the Honor Prison Farm was too close to Des Moines, Urbandale, and Clive, which were rapidly growing out towards the Farm. Bids were requested and after some delay, including the rejection of one set of bids, the Farm was sold to Rollo Bergeson and Associates, the highest bidder. The sale price was $\$ 751,000$ for the 687 acres in the farm at the time or an average of $\$ 1,093$ an acre.

Members of Living History Farms, a non-profit foundation organized for educational and historical purposes in 1967, discussed with Mr. Bergeson the possibility of buying some of his land for their project. Eager to see at least a portion of his tract used for public benefit, Bergeson agreed to an option for 171 acres west of the Interstate and north of Hickman Road. In February 1969 Living History Farms purchased this tract from Mr. Bergeson.

In May of $1970 \mathrm{Mr}$. Bergeson signed a long term lease 
and option with Living History Farms for 165 acres east of the Interstate and north of Hickman Road, a tract which contains the Flynn Mansion, barn, and other buildings. Thi tract is connected with the Living History land west of the Interstate by the underpass which the State Farm obtained in providing land for the Interstate.

At this writing, Living History Farms has its Farm of 1840 well underway, is planning the development of the other two farms, is tentatively planning the development of a countyseat town of 1870 , is considering restoration of the stately house, and is planning repairs, paint and new shingles for the old barn. For the old barn a group of lumber dealers in Des Moines and nearby towns have contributed the new shingles; several contractors have provided scaffolding and equipment, and Carpenters Local Union No. 6, AF of L-CIO has offered to reshingle the barn roof. In the summer and fall of 1970 , two harvest festivals were held with the leadership and help coming from farmers and others living near the project in most cases. With this kind of cooperation and gifts, and with a dedicated Board of Governors, a bright and active future can be predicted for the 600 acres which E. R. Clapp sold to Martin Flynn in 1867.

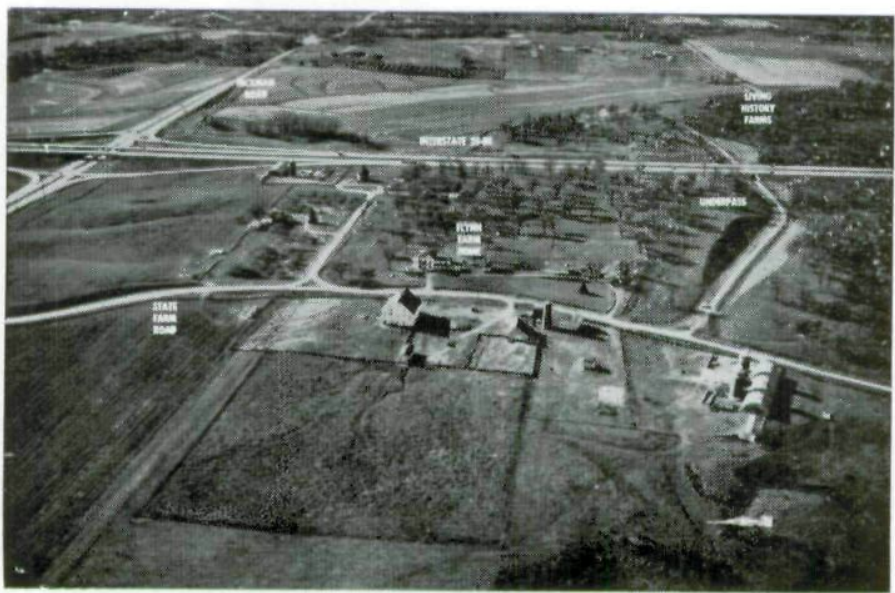

Courtesy of Des Moines Tribune

Fig. 6 Aerial View of tract of land which was given to Living History Farms by Rollo Bergeson family in Dec. 1970. This tract is valued at $\$ 280,000$ and includes the Flynn Mansion. The tract is located in the upper center of the picture, bounded by the Interstate on the west and by roads on the other three sides. 
Copyright of Annals of Iowa is the property of State of Iowa, by \& through the State Historical Society of Iowa and its content may not be copied or emailed to multiple sites or posted to a listserv without the copyright holder's express written permission. However, users may print, download, or email articles for individual use. 